6-1-2015

\title{
Taking the engineering path to business leadership and entrepreneurial success in Canada and USA
}

\author{
Emeric Solymossy \\ Western Illinois University, e-solymossy@wiu.edu \\ Andrew C. Gross \\ Cleveland State University, a.gross@csuohio.edu
}

Follow this and additional works at: https://engagedscholarship.csuohio.edu/bus_facpub

Part of the Entrepreneurial and Small Business Operations Commons

How does access to this work benefit you? Let us know!

Publisher's Statement

The final publication is available at Springer via http://dx.doi.org/10.1007/s11365-014-0298-3

\section{Original Published Citation}

Solymossy, E. \& Gross, A. (2015). Taking the engineering path to business leadership and entrepreneurial success in Canada and USA. International Entrepreneurship and Mangagement Journal, 11(2), 393-408. doi:10.1007/s11365-014-0298-3

This Article is brought to you for free and open access by the Monte Ahuja College of Business at EngagedScholarship@CSU. It has been accepted for inclusion in Business Faculty Publications by an authorized administrator of EngagedScholarship@CSU. For more information, please contact library.es@csuohio.edu. 


\title{
Taking the engineering path to business leadership and entrepreneurial success in Canada and USA
}

\author{
Emeric Solymossy • Andrew Gross
}

\begin{abstract}
A cross-sectional longitudinal study of Canadian graduate engineers yielded unexpected percentages of engineers gravitating towards entrepreneurial opportunities. The aggregate of the classes of 1954, 1959, and 1964 demonstrate entrepreneurial / intrapreneurial outcomes at a rate that is many times higher than the general population. The rate is well over double the rate cited previously for engineers intending to pursue entrepreneurial outlets (Tremblay et al. 1998; Tremblay et al. 2007). This paper explores possible reasons for those findings. Existing literature is combined with a crosssectional, longitudinal study of graduate engineers. Interpretive insight is offered from a separate exploratory study investigating the value of knowledge. Seeking to understand the high incidence of engineers gravitating to entrepreneurial opportunities, we refer to a separate study exploring potential knowledge; how knowledge is valued, and how the value of knowledge is shared between the organization and the employee. We present a framework for knowledge to be applied, or potential. Firms that saw potential knowledge in some employees recognized and captured its economic value. Instead of sharing the value generated by the knowledge with the individual, the firms indicated increasing the work load and adding responsibilities to the individual. We advance a proposition that the selection and training of engineers emphasizes potential knowledge, which is a form of intellectual property; a resource with economic value. As a valuable resource, one can expect the individual to seek a reasonable return on this asset. If the firm appropriates all of the returns, it is reasonable to expect the individual to seek a higher personal return from his or her intellectual property. Those with potential knowledge may seek alternative opportunities to capture some of the value of their intellectual property for themselves, and thereby pursue entrepreneurial outlets even if they had not initially intended or desired to do so.
\end{abstract}

E. Solymossy $(\bowtie)$

Western Illinois University, 3300 River Drive, Moline, IL 61265, USA

e-mail: E-Solymossy@wiu.edu

\section{A. Gross}

Department of Marketing, Monte Ahuja College of Business, Cleveland State University, Cleveland, OH, USA

e-mail: a.gross@csuohio.edu 
Keywords Entrepreneur Intrapreneur $\cdot$ Knowledge $\cdot$ Potential $\cdot$ Value $\cdot$ Competetive advantage

\section{Background}

Engineering as a field of study, was formalized in France in the 18th Century. Engineer has its roots in the Latin word ingeniare, which means to devise in the sense of construct, or craftsmanship, and is related ingenuity. Engineering as a discipline, began to provide support services for the Military. The principle objective was to design and construct necessary infrastructure, such as roads, bridges, and fortifications. The first school that offered engineering education in America was the U.S. Military Academy at West Point, beginning in 1802. The first school - which still exists today - that taught civil engineering is the Rensselaer Polytechnic Institute, which awarded the first engineering degree in 1835 (Unknown 2013a). In Canada, the beginnings of Engineering Education occurred in 1854, with lectures by Thomas McMahon Cregan at King's College, which became the University of New Brunswick. (Unknown 2013 b). There was considerable social and political pressure to close the school, with calls for the curriculum to be more practical (ibid).

The training of engineers was crucial to the development of North America. Initially, this focused on canals, roadways and railways for the transportation of goods and people. As the population evolved from an agrariarian to a more urbanized and industrialized population, engineers were required to develop of water and wastewater systems. "Engineers and scientists are the wealth generators of nations. It is their products and services that realize increased gross domestic product and improve the balance of trade" (ibid., p 1). Scientists invent and discover; engineers apply and innovate. Venture capitalists provide financing, entrepreneurs seek new products to bring to markets; and commercialization is at the heart of such linkage. Engineers bring skills to this process via problem-solving, analytical thinking, and design-orientation (Solymossy et al. 2012).

While industry for many years called for dual ladder or parallel path of advancement, engineers found that this was often not viable, so many moved into management for higher remuneration and job satisfaction. This trend was reinforced by reports that some technical skills were not utilized, while others have become obsolete. However, engineers' analytical, problem-solving skills serve them well as they execute managerial tasks. A previous paper (ibid.) presented primary and secondary research on this topic, including a major cross-sectional longitudinal study of Canadian engineering graduates with three distinct cohorts followed for 45 to 55 years.

As evidenced by the history of King's College (Unknown 2013b) there continues to be debate about what a "proper" engineering curriculum should look like at the undergraduate (and graduate) level. Associations, government agencies, and other groups go back and forth in their emphasis on the role of science, design, and craftsmanship courses with no clear resolution (White 2002; Wilson 1998).

For many decades in Canada, and USA, government agencies, engineering associations, as well as scholars, analyzed the labor market for various occupations and specifically professions. Two authors developed a dynamic model of occupational choice and applied it to the engineering profession (Ryoo and Rosen 2004). They found that demand responds well to wage levels and "demand-shifters," while supply 
(university enrollment) is quite responsive to career prospects. Shortages seldom exist and "hence subsidies to build technical talent ahead of demand are misplaced." This is a notable conclusion.

\section{Primary surveys, Canada, 1965 and 2009—scope and methodology}

In 1965, one of the authors had undertaken his doctoral dissertation on the topic of engineering manpower in Canada; results were then reported in various refereed journals (Gross 1969a, b). The study involved three cohorts of electrical engineering graduates -those from 1954, 1959, and 1964- from all Canadian universities. The database consisted of 1177 individuals with names obtained from the alumni associations of the 19 universities. There were 819 respondents for a truly high response rate of $70 \%$. The survey forms (pre-tested in 5 companies in Ontario) were mailed out with a cover letter signed by the author, a "fellow engineer," from the University of Saskatchewan.

In 2009, this author re-visited those nine universities that had graduates in each of the three cohort years (however, two French-language universities exempted themselves). This procedure allowed following the three cohorts through the years. Despite a much shorter survey form, the response rate in 2009 was much lower, coming in at $26 \%$, with 220 alumni responding from a potential pool of 838. This was not unexpected as some graduates have retired, died, or had no postal addresses. In both surveys, names and addresses came from university alumni associations. In the more recent case, these associations - partly to keep control of names- sent out the survey form themselves.

In 1965, the five-page survey focused on demographics, education, positions held, function, mobility, income, plus satisfaction and utilization pertaining to both education and the current job. The 2009 short survey form omitted questions on demographics, degrees, and income, but otherwise focused on identical aspects. Together, the surveys provide a good cross-sectional follow-up and a longitudinal view in the aggregate figures (since we did not match up individuals between the two surveys). The data consist of two different time frames for the graduates, at the start of their careers and over four decades later, at the end of their careers.

\section{Primary surveys, Canada, 1965 and 2009—context and highlights}

During the 1965-2009 period several broad trends converged that had a strong impact on the three cohorts. First, the Canadian economy evolved from a miningmanufacturing mode into a broader mix with services coming to the fore. Computer and communication technology has seen rapid advances. Second, the nature of skill sets required by various industry sectors lined up well with reforms in engineering education. The evolving curriculum both reflected and influenced the notion that technical and managerial skills will be in demand throughout one's career. Third, career stability took on new meaning: graduates seldom stayed with one employer for decades; instead, they were ready to cross industry and functional boundaries in an expanding economy. Such mobility was strongly influenced by the demolition of the myth of dual ladder or 
parallel path of advancement. To gain higher salary and recognition, the move to managerial positions gained strength.

As shown by Table 1 (see Table 1, next page), the majority of engineers began in technical activities, however, over $50 \%$ of each cohort gravitated towards management as their principle function.

The statistics in Table 1 clearly indicate significant shifts in all three cohorts during their long careers. Many did move away from engineering or related technical work; some have taken on other high level work (defined here as: teaching, research, or consultancy); and, there was strong movement toward posts in executive-administrative ranks. Even more significantly, we can report that as of 2009, $21.4 \%$ of the class of $1954,24.6 \%$ of the class of 1959 , and $30.1 \%$ of the class of 1964 held a top level, leadership role in 2009 with oversight and decision-making responsibilities for innovation in products or processes, and having one of the following titles: owner; managing director; chairman; executive vice-president or president. Several listed their title as executive, elsewhere indicating that they started the firm. We argue that becoming the executive directing innovation, performing strategic planning, and assuming responsibility for envisioning the necessary product, market, and management strategies qualifies the individual as an intrapreneur, and demonstrates entrepreneurial outcomes (Pinchot 1985.) Definitional issues with the concept of an entrepreneur cited by Mark and Johnson have still not been resolved, (2003). Like them, we find the broad definition used by Carland et al. (1984) as being relevant in the international domain: "an entrepreneur is an individual who establishes and manages a business for the purpose of profit and growth." (Mark and Johnson 2003, p.896)

We estimate that one-fourth of these worked in small to medium-size firms lending further credence to an entrepreneurial positioning. This observation is more pronounced when looking at the trends manifested by comparing the cohorts. The class of 1954 evidenced $21.4 \%$ transitioning to entrepreneurial/executive positions, while the class of 1959 and class of 1964 exhibit 24.6 and $30.1 \%$ respectively (see Fig. 1). Each successive cohort shows considerably higher migration to entrepreneurial and executive opportunity. This may, in part, be due to the increasing role of technology in business, and the inclusion of computers and information technology within the engineering curriculum.

To understand the extent of the entrepreneurial activity among engineering graduates, we sought data for comparison. Research from 1and1 (an Internet service provider) indicates that $53 \%$ of Americans have "seriously considered" their own business start-up, of which $40 \%$ (20\% of respondents) considered a side venture to supplement

Table 1 Canadian engineering graduates by job function/principal activity

\begin{tabular}{|c|c|c|c|c|c|c|}
\hline \multirow[t]{2}{*}{ Function/Activity } & \multicolumn{2}{|c|}{ Class of 1954} & \multicolumn{2}{|c|}{ Class of 1959} & \multicolumn{2}{|c|}{ Class of 1964} \\
\hline & 1965 & 2009 & 1965 & 2009 & 1965 & 2009 \\
\hline Technical/Engineering & $61.3 \%$ & $26.8 \%$ & $59.6 \%$ & $16.4 \%$ & $54.8 \%$ & $21.4 \%$ \\
\hline Other high level & $11.8 \%$ & $16.7 \%$ & $18.5 \%$ & $21.3 \%$ & $15.2 \%$ & $17.5 \%$ \\
\hline Executive/Administrative & $6.2 \%$ & $55.0 \%$ & $8.2 \%$ & $52.4 \%$ & $7.7 \%$ & $51.5 \%$ \\
\hline All other & $20.7 \%$ & $1.5 \%$ & $13.7 \%$ & $9.9 \%$ & $22.3 \%$ & $9.6 \%$ \\
\hline
\end{tabular}




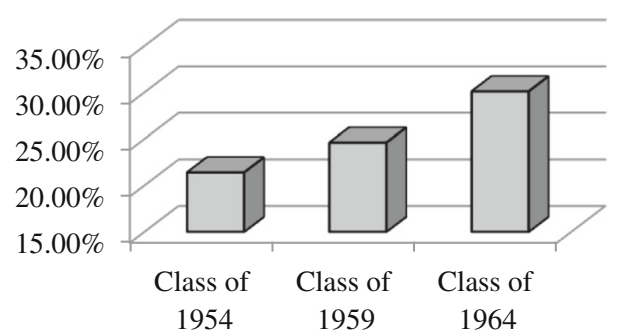

Fig. 1 Evolution of Canada engineering graduates to entrepreneurs and executives (Gross 1968, 1969a, b; and Solymossy et al. 2012)

their existing employment income (WSJ 2013). This gives insight to intention, not outcome. While many seriously consider starting a business, in reality very few actually do. One source puts the percentage of the American households (not individuals) that own a business at $11.4 \%$ in 2004. (Sachoff 2008). The data used from which this is derived, however, is not available. Never the less, it is well understood that entrepreneurial desire or intention is not always carried forward to venture initiation.

Venture start-up activity among the general public is sampled and reported by the Kauffman Index of Entrepreneurial Activity (KIEA). The KIEA measures new business owners in their first month of significant business activity, taking snapshots in time of those working $15 \mathrm{~h}$ or more in the first month of their venture. Comparison with the engineers, however, is problematic at best. KIEA recognizes activity that might be parttime or full-time, supplemental or primary income, temporary (e.g. seasonal), or enduring. The KIEA represents a cross-sectional measurement of inception, while the data from the engineers provides indication of successful and enduring operations. Extrapolating the KIEA data for comparison is also problematic since the 5 year survival rate for start-ups is $50 \%$ (Shane 2012). Never the less, 17 years of data are reflected in the Kauffman Foundation's current survey (Fairlie 2013). The data of these averages shows $0.30 \%$ initiations per month.

Data from the engineers reveals that $21.4 \%$ of the class of $1954 ; 24.6 \%$ of the class of 1959 ; and $30.1 \%$ of the class of 1964 had entrepreneurial/intrapreneurial outcomes. From one cohort to the next, the entrepreneurial rate is increasing. The class of 1964 shows an extremely high rate compared to all available data. The data from the three cohorts is more than double the rate cited previously for engineers who had expressed a desire to pursue entrepreneurial outlets (Tremblay et al. 1998, 2007).

These findings are tangential to data reported in Canada and USA, namely that a high percentage of chief executives have an engineering degree (e.g. Felicelli and Allen 2006). Research shows that the career ladder for engineering graduates is diverse (Lavoie and Finnie 1998). Some stay with engineering, some move into projectbased careers. The move to management occurs as early as 3 to 5 years after graduation. Regardless of when a technical career is left behind, the undergraduate engineering degree is seen as valuable. Autonomy is an important element in professional development; career success appears strongly related to one's views on professional as well as organization values. In several studies, engineers clearly demonstrate entrepreneurial tendencies, with about $10 \%$ of the engineers hoping to launch their own business (Tremblay et al. 1998, 2007). As with the Kauffman research, Tremblay's research isn't truly comparable, but provides another subjective reference point. Tremblay and his co- 
authors, in a succession of studies, sought to understand why engineers chose one career path over another - looking at project-based, managerial, entrepreneurial, and hybrid path that combines technological tasks with managerial duties. Our study of engineer graduates exhibits two to three times as many actually having successfully pursued entrepreneurial outlets as Trembley et al. reported expressing entrepreneurial desire/intention (ibid). While much of this difference can be attributed to definitional issues and different research focus, it does suggest that many engineers gravitated towards opportunities which were not part of their original career plans.

Gurka (2011) argues that much like in the 1940s, engineers could make the best business leaders because they are "tech-savvy, analytical, meticulous, taking risks, but calculated ones" (p25). She further notes that engineers are often leaders of small and start-up companies.

The developmental background of S\&P 500 chief executives has been followed in detail through annual reports, all of them titled "Route to the Top," by Spencer Stuart, an executive search firm. The results from the 2004 to 2008 studies show engineering as the top undergraduate degree at $20 \%$ to $22 \%$, followed by economics at $11 \%$ to $15 \%$, and business administration at $13 \%$ to $15 \%$ (Felicelli and Allen 2006 etc.). Paralleling this, among Fortune 500 firms, which are generally larger than the S\&P 500 , about $20 \%$ of the chief executives had an undergraduate degree in engineering, higher than any other specialization. (Cox 2011). This agrees with yet another study of the Fortune 500 CEOs by a think-tank in Minnesota, showing that $21 \%$ of chief executives hold engineering degrees, again, significantly exceeding those with accounting or business degrees (Martelli and Abels 2010).

Business and industry have changed in the past 50 years. In addition to the emergence of computers, telecommunications and information technology, the context for business has become global, and competition has intensified on all points. This complexity appears to favor engineers, who acknowledge having an "excellent background for a technology company” (engr. respondent \#25). Engineering education emphasizes problem-solving, solution orientation with a solid mathematical foundation. Repeated references were made to problem analysis and solution orientation, such as "Engineering teaches you to analyze problems, both technical and non-technical, and find the cause or solution, as the case may be. Engineering also teaches you how to find information. You don't have to know everything, just know where to find it" (engr. respondent \#19). This reinforces career promotion and ascendance in an organization, but not necessarily entrepreneurship seeking.

The 1965 surveys indicated that many of the graduating engineers intended to work for others. This was confirmed in follow up interviews, and resonated with one of the authors (a graduate engineer who sought to work for another, yet ended up being a serial entrepreneur). The question of why so many engineers gravitated towards entrepreneurial outlets evolved into questioning why they were unable to achieve their objectives through traditional firms. After all, every organization relies on innovations in products and processes to provide a competitive advantage. Engineers apply and innovate. Entrepreneurs seek new products to bring to markets, most of which require various levels of engineering. Commercialization is at the heart of the linkages between invention, innovation, and a marketable product. Engineers bring unique skills to this process via problem-solving, analytical thinking, and design-orientation (Whittaker 2001; Solymossy et al. 2012). 
Respondents identified autonomy as an important element in their professional development. There is a pattern of responses stating that innovation and problem solving are likewise important to an engineer's career development. Each of these implies the acceptance of some risk. Some of the commonly identified characteristics of entrepreneurs include; autonomy, innovative behavior, and risk-taking; the same characteristics cited or implied by the engineers.

The problem-solving approach of engineering, the blending of creativity and systems thinking with logic are unique. Some have argued that this is the nexus of science and engineering. The workplace, however, maintains a practical view of knowledge: does it impact profitability? We know entrepreneurs have a unique focus on value, (Baker and Echarananta 1999; Lowendahl et al. 2007) and future orientation (Das and Teng 1998; Covin and Slevin 1989; Lumpkin et al. 2010). It is interesting to note that numerous researchers have argued that long-term orientation is positively correlated with innovation and success, and inversely correlated with risk-taking (ibid) (Heunks 1998). Intuitively, this positions engineers well for hyper-competitive, technology oriented ventures. Engineers are trained to be creative, yet deliberate in seeking to minimize risk. This might explain why so many initially sought to work for others. Engineering is more than just a field of knowledge, or a set of task-specific skills. "It is an approach to the world, a strategic sensibility different from a politician's. It favors innovative solutions over incremental fixes, calculations over consensus." (Keller 2013, p A17)

David Birch's seminal work "The Job Generation Process" (1979) identified entrepreneurs as being at the leading edge of economic development, value creation, and wealth building. The expansion of technologically-oriented businesses have not diminished entrepreneur's ability to create value (Amit and Zott 2001), but have placed engineers in a unique position to capitalize on their knowledge. Value creation, however, is not the same thing as value capture or appropriation (Bowman and Ambrosini 2000; Lepak et al. 2007; Felin and Hesterly 2007). Organizations exist to convert value to sustainable competitive advantage, and to capture the wealth created in the process.

There are volumes of research looking at knowledge. We are specifically interested in knowledge as a valuable resource, at the intersection of individual and organizational knowledge. One framework that supports this approach was presented in Matusik and Hill's work on knowledge and competitive advantage (1998). In this context, knowledge is a multi-dimensional construct with two distinct typologies of knowledge, and three distinct taxonomies to knowledge. It should be noted that typologies seek to classify multidimensional concepts (ambiguous, difficult to measure), while taxonomies differentiate items on the basis of observable (empirical) differences that can be identified and measured to some extent (Smith 2002). Knowledge's two typologies are component knowledge and architectural knowledge. Component knowledge focuses on components of the whole; elements, specifics, and details. Architectural knowledge is broader, more inclusive, and integrates the components into a whole, complex system (Baldwin 2010).

Beyond this conceptual idea of knowledge focusing on elements or the totality, knowledge is also differentiated by two primary taxonomies assessing where the knowledge resides: Public or Private, and within the Private taxonomy, a sub classification of individual or organizational (collective). Private refers to whether the knowledge is confined to a specific firm, or is general knowledge (for instance, the coding for the Mozilla Firefox browser is open-sourced, hence, it is public knowledge). The 
coding for Internet Explorer is specific to Microsoft, hence private. Within a specific firm, the knowledge may be further confined to an individual, or shared within the organization. The third classification (taxonomy) of knowledge relates to the nature of the knowledge itself (rather than where it resides). Knowledge can be tacit (Polanyi 1958), or explicit. Explicit knowledge, also known as formal, or codified knowledge, is comparatively easy to transfer, since codification makes it easy to transmit (writing or drawing.) On the other hand, transfer of tacit knowledge requires extensive personal contact, intensive feedback (within context), regular interaction and trust. The typologies and taxonomies can be combined into a basic knowledge chart, as depicted in Fig. 2 (See Fig. 2).

Many of the engineering graduate respondents commented on the application of their education. In addition to relying on the capability to learn, the flexibility to adjust, and having the knowledge, skills (e.g. technology) and ability to be creative and innovative was reported. Respondents treated their knowledge as a valuable personal and commercializable resource. Researchers (primarily in Human Resources) have considered knowledge, skills and abilities as a resource (e.g., Sevens and Campion 1994). Others have looked at a combination of knowledge and competence (e.g. Li and Calantone 1998). These perspectives are similar, as they look at knowledge as being a vehicle that generates an economic return. Valuing the bearer of the knowledge, however, requires recognizing individual, tacit knowledge as a valuable resource. While some question whether personnel can be a sustainable competitive advantage to the firm (Hoffman 2000), we submit that the question should be focusing on the nature of the knowledge rather than the personnel. Research, while sparce, is has begun focusing on knowledge (versus the person) as a valuable resource (for example; Baldwin 2010; Felin and Hesterly 2007; Hunt and Morgan 1995; Lowendahl et al. 2007; Srivastava et al. 1998).

\section{Insight from research into the potential knowledge and the value of knowledge}

Engineers are different in how they think. "If God were an engineer, we'd have a new world every 7 days" (Vesey 1991). The knowledge and skills necessary for properly

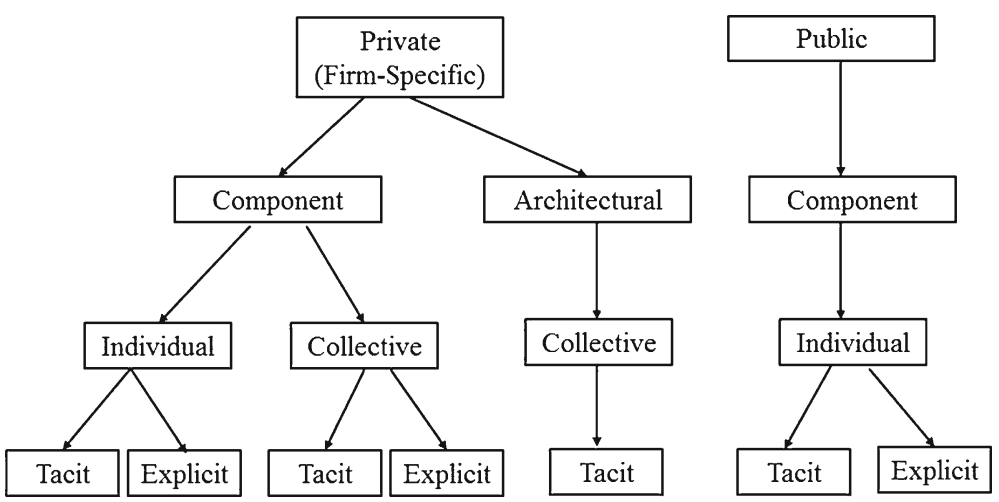

Fig. 2 Organizational knowledge components (adapted from Matusik and Hill 1998) 
completing known tasks, regardless of the complexity are not the same as the knowledge and skills necessary for dealing with unknown tasks. We maintain that dealing with the unknown involves differences in when and how knowledge is utilized.

The combination of high entrepreneurial outcomes and acknowledged differences in how engineers think occasioned us to reflect on research into types of knowledge. In addition to literature, we reviewed data from a separate, on-going study, exploring the concept of potential knowledge, and the value of knowledge (hereafter referred to as PKV) (Solymossy 2011). Begun in 2002, it is an on-going exploratory inquiry using interviews. The principle objective of this exploration is to gain insight into how the economic value of knowledge is shared (between individuals and the organization). Early in the conceptual development phase, a colleague from Russia (Dr. Sergei Fedin) brought up the question of potential. Much of the existing literature and much of the discussion pertaining to knowledge focuses on the application of knowledge. Paralleling this to the world of physics (and considering knowledge as energy), allows one to consider two states of knowledge: kinetic (applied, or energy in motion), and potential (having energy by virtue of its condition, or its relative position). For instance, a charged battery may be disconnected (hence, no applied energy), yet by virtue of its condition, has energy, and a capacity for utilization. From this framework, we define applied knowledge as the knowledge that is being utilized in the performance of valueadded work activities that exist and are well defined.

Potential knowledge, on the other hand, is defined as the capacity, latent ability, and the adaptability to transfer knowledge from one context to another, and to acquire any additional knowledge and skill to apply to emerging, new opportunities, and or to create new knowledge. As a newly proposed construct, PKV research is strictly exploratory and developmental, lacking many of the measures traditionally associated with scientific research. We were interested in whether this distinction in knowledge is relevant in the real world of business, and sought to learn how businesses valued knowledge. Furthermore, we were curious as to how much of the valuation assigned to knowledge was on the basis of industry and sector or work responsibility.

We conducted interviews with 70 individuals (within 67 different organizations), each in a leadership role within their organization. Some interviewees were engineers, however, most were not. The organizations represent a broad cross section of classifications and types, ranging from large, established manufacturing firms to emerging high tech firms. As we were interested in a broad range of responses, governmental entities and non-profit organizations were also targeted. For anonymity, individual quotations from interviewees will be referenced to numbers, rather than to their (or their organization's) names.

Reviewing the raw data from the PKV research with the question of why so many engineers became entrepreneurs (when many of them sought to work for others) caused some of the findings to appear very relevant and insightful. A large majority of the interviewees (94\%) did not fully grasp the concept of potential knowledge even after it was defined and explained. The perspective maintained by overwhelming majority of managers and executives was that knowledge only has value if it can be applied. This concurs with existing writings. Kotelnikov (2001) maintains that "Knowledge has no intrinsic value of its own - it is only relevant when it's used." The majority consensus is that what counts to organizations is the ability to apply knowledge. Output can be measured. All value is determined by measurable performance. 
Most of the subjects (reflecting their organizations) had difficulty reconciling the conceptual difference between applied and potential knowledge. Many kept referring to education; "the willingness to learn" (PKV interview \#26), and that more education equaled more potential; "the more you learn, the more you earn" (PKV interview \#37). We argue that education may be related to, but is not equivalent to potential knowledge. The commonly held perspective was that potential meant suitability for promotion; the individual could handle more complex tasks. It is possible that embedded definitional biases of employee potential prevented respondents from considering alternative frameworks. Even among the few (four) firms that understood the conceptual difference in types of knowledge, the responses were unexpected. While it was commonly held that potential knowledge was in the form of both knowledge and attitude, applied knowledge was still valued much more than potential knowledge. The overwhelming belief is that experience counts; "a college degree should be called a learner's permit" (PKV interview \#72). When we delved further by inquiring about the quality of experience (e.g., was it 10 years of experience, or 1 year of experience ten times), application and output were again cited. More insight was offered by the statement "potential knowledge is a cost, not a benefit." (PKV interview \#3 - an SME transportation firm).

Few $(6 \%)$ of the interviewed firms recognized the difference between applied and potential knowledge (and saw value in it). While initially surprising, this reflect the relative rarity of entrepreneurs already found in literature. We asked these respondents how the value of the knowledge was shared with, or communicated to the employee. The responses indicate more work, more responsibility, but not more money (one firm commented on allowing the few high-potential knowledge employees a little more latitude (quasi-indirect compensation). As stated by another interviewee: "There are no additional forms of compensation; direct or indirect. High potential people are fasttracked" (PKV interview \#20). Another interviewee commented that "high potential knowledge people are utilized by serving on more committees and task forces" (PKV interview \#31). This can be interpreted as promotions and advancements sooner than others, likely resulting in higher pay in the future. Not only is the compensation deferred (future), we argue that it is still oriented to pay for performance of tasks increased pay for performance of tasks with increased responsibility.

Perhaps because of the geographic location of the firms (Midwest United States), there was a pattern of constraints mentioned by the interviewees. Job classification constraints, union influence (even if not a union shop), job-based pay systems, and perceptions of fairness by other employees each were cited as reasons for the value not being shared. Never the less, most of the organizations have no way of determining the value of knowledge: they focus on and only value output - post hoc compensation. Yet intellectual assets have been argued to account for $80 \%$ of every dollar of stock market value (Kennedy 2001). Intellectual assets are intangible assets (Srivastava et al. 1998). But, as a marketable asset, we propose that high-potential-knowledge persons will have a sense as to whether or not their unique asset is being appropriately valued and rewarded.

We were also interested in the life of applied knowledge - using the half-life concept from physics: at what point (in time) is half of the value of applied knowledge lost? What was surprising here is that we expected more knowledge-intensive firms to have a shorter time-value of knowledge. It was the opposite. The high-tech and engineering 
firms seemed to agree on knowledge losing half of its value in 5 years. Where less technology was used in the production of goods or services, the firms identified the halflife as 1 to 3 years. This could be related to the difficulty most interviewees had with the concept of potential knowledge. It may also be related to a culture of opportunism (an entrepreneurial attitudinal orientation) (Solymossy 2000). The ability to scan the market environment, be familiar with evolving trends in production materials and processes (in both manufacturing and service enterprises) and to move decisively to create opportunities that others do not envision requires proactive positioning, organizational flexibility, and people possessing and using potential knowledge.

Through the interviews, we observed that many of the interviewees themselves did not appear to have potential knowledge. This is arguably a very subjective assessment. At the same time, and by analogy; Imagine a person living in India, conversant in Dravidian (the principal language in India), but none of the other several hundred other languages represented in the country. If an individual from another region is speaking, how will the hearer know if the individual is speaking Munda, Dogri, or Bodo? They will fail to understand the message. Furthermore, they will not even recognize what language is being spoken - it will be an alien language. One interviewee even commented that the owner might understand the difference between applied and potential knowledge, but they did not (yet they were responsible for all hiring and compensation decisions) (PKV interview \#51). This indicates that there is recognition that the business owner utilizes a different level/type of thinking, even though the person being interviewed is not capable of understanding exactly what it is; like a foreign language.

Another question that arose from the time-value discussion of knowledge is whether the time-value is based purely on application, or whether it involves certain aspects of the potential for learning and adaptation? An organization relying heavily on potentialknowledge employees might have more confidence is their ability to adapt to changing complexities and technologies in the workplace. This allows them to capitalize on perceived opportunities. An organization that relies solely on applied knowledge (performance of tasks) may have less confidence in an individuals' ability to adapt, hence perceive a shorter knowledge half-life.

While potential knowledge is a concept that resides in an individual, adoption and application of the knowledge to yield a competitive advantage would need to be shared, and as a result, become an organizational level consideration. The value-added nature of potential knowledge, therefore, will be embedded in the application and resulting competitive advantage that is produced for the organization (See Fig. 3).

Bharadwaj et al. (1993) argue that the need for innovation as a source of competitive advantage increases with greater complexity. Organizations capture the economic value derived from the product or service. Chandler (1990) demonstrated that IBM and Bayer succeeded by making heavy and risky investments in compiling organizational knowledge and capabilities, allowing them to exploit opportunities. Cohen and Levinthal (1990) posited that the ability of the organization to bring in and absorb new knowledge was vital to a firm's success, and requires investment in absorptive capacity.

While the organization focuses on the value-added nature of knowledge and appropriates the value derived from it, our interviews indicate that they may not share the value with the individual. As the research progressed, we began exploring whether these high potential employees may be exiting firms that do not share the acquired 


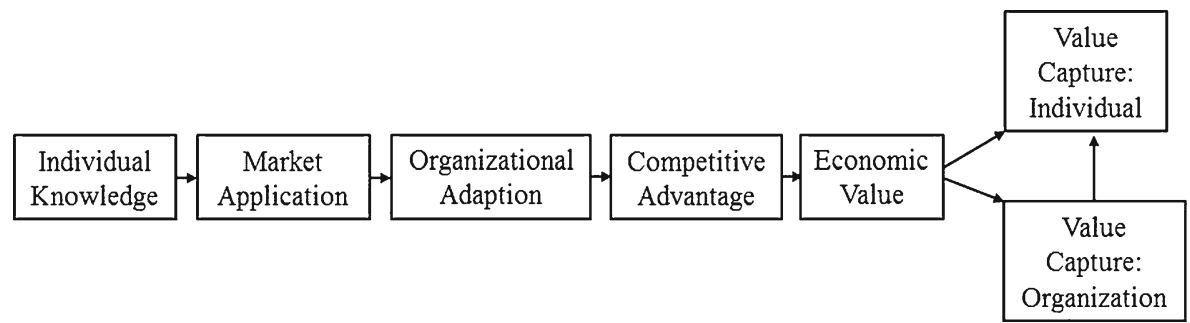

Fig. 3 Value creation path: potential knowledge value capture (Solymossy 2011)

value with the employees. Might they be leaving the firm to start their own, or seek an opportunity that rewards them more? One firm clearly understood the impact of value sharing, and stated that high-potential-knowledge personnel are "able to sell themselves to the highest bidder" (PKV interview \#30). While research has looked at change as a catalyst for turnover of high-potential employees (e.g., Baron et al. 2001), there is limited research into the motivations behind their turnover.

Right Management surveyed 2,080 internal and external recruiters, human resource executives and hiring managers from 17 countries, and representing more than 20 industry sectors. They found that $59 \%$ of North American respondents expect turnover rates to increase in the next 5 years (Unknown 2011) (see Fig. 4). How might the concept of potential-knowledge employees impact these projections?

While research into turnover of high-potential employees is very limited, a combination of Von Glinow (1998), and Lee and Maurer (1997) provide useful insight into our inquiry. Von Glinow describes the characteristics of professionals in hightechnology enterprises, which includes engineers and other knowledge workers. Of his five characteristics, two are very relevant for our utilization. First, they have expertise in an abstract knowledge base that was acquired over a long period of time, and second, these professionals perceive a basic right to work autonomously. Lee and Maurer (1997) argue that knowledge workers "do not add value to the firm because of their labor per se; they do not add value to the firm because of their work histories per se; but they do add value to the firm because of what they know." (Emphasis in the original, p 248.) They further categorize voluntary turnover motivation of knowledge workers into four different typologies: 1) from good to better; 2) enough is enough; 3) time to move on; 4) changing aspirations.

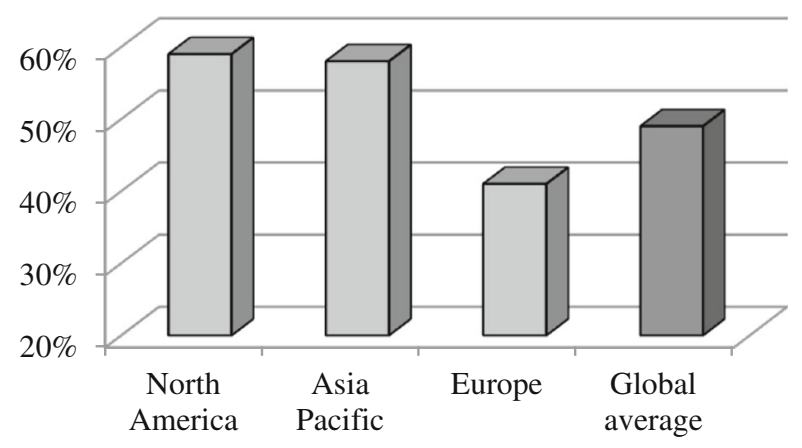

Fig. 4 Global expectations of higher turnover in next 5 years (from 2011 survey by Right Management, division of Manpower, Inc.) 
The likelihood that value is not shared by the organization (in what is perceived as fair by the individual) implies a motivation for exiting. Add to this the evidence from those few organizations that do recognize potential knowledge workers, who "reward" them by giving them additional tasks, duties and responsibilities. Imagine a hardworking farmer who owns a good horse trained to pull the plow. The farmer learns that he can also pull a wagon, so now he pulls the wagon after the plowing is done, hauling freight and transporting the kids. Then, by accident, the owner further learns he is gentle with riders and can jump. This is an entirely different level of knowledge, abilities and skills, and demonstrates significant adaptability. Now, junior and all of his friends practice riding and jumping; after the plowing and after pulling the wagon. Instead of a good rub-down, extra ration of grain or more hay; the horse is worked until he breaks down, bucks up, or breaks out. As suggested by Lee and Maurer (1997), enough is enough, time to move on!

In the case of a knowledge worker, potential knowledge is a form of intellectual property, a valuable resource. As a valuable resource, one can expect the individual to seek a reasonable return on his/her asset, commensurate with the risk involved. If the firm seeks to appropriate all of the returns, it is reasonable to expect an individual to seek to maximize their personal return from their intellectual property, and gravitate towards more satisfying or rewarding opportunities.

We propose that individuals possessing potential knowledge may seek to capture some of the value of their intellectual property by either becoming entrepreneurs (higher personal risk), or by aggressively pursuing intrapreneurial opportunities through executive positions (less personal risk). Both alternatives would be suitable for engineers seeing more autonomy, decision-making discretion, and personally capturing value for their knowledge. We further contend (as previously demonstrated by research) that engineers have a broader scope of knowledge, different ways of thinking, are specifically trained in creativity and innovation, and have distinctive problemsolving skills (Moti 2006; Coleya et al. 2007). This implies that they may have some of the elements of potential knowledge, and would also have the skills and ability to apply their knowledge in an innovative fashion for the creation of a competitive advantage. This is relevant whether they were working for themselves or for another.

While certainly not conclusive, the concept of potential knowledge and evidence suggesting that its value is appropriated and not shared, does offer a viable insight into the entrepreneurial outcome for many engineers. For our engineering study to demonstrate two to three times the entrepreneurial/intrapreneurial outcome of previous research (significantly greater than the rate of the general population) is astounding. This research generated new questions and opportunity for further research. Research should further explore the reasons why so many engineers set out to work for others, yet ended up pursuing entrepreneurial opportunities. As the data from the 2009 study could not be tied to individual responses from the 1965 study, it is not possible to determine how many engineers intending to be entrepreneurial did in fact do so, and also how many had not intended an entrepreneurial careers, yet gravitated to one.

While this research combines a predominately quantitative, longitudinal study of engineering graduates with a qualitative study into potential knowledge, we are mindful of some conceptual ambiguity. Admittedly, the PKV research is exploratory, and may be considered as lacking proper foundation because it has not been previously researched. One of the purposes of exploratory research is the discovery of themes, 
and from those themes the emergence of variables of interest for subsequent research and testing. Because the two projects were distinct and different, the operating definition of potential knowledge may not exactly apply to engineers. We are mindful of work that separates engineers into three career-based prototypes (Allen and Katz 1995), and the longitudinal study was not based with these prototypes in mind. Likewise, we are aware that considering an engineer that becomes an executive of a larger firm might not be considered by some as being an entrepreneur since it lacks the "new venture" aspect that some focus on. Never the less, we maintain that the decision-making discretion, necessity for strategic planning, and ability to drive innovation in pursuit of profit and growth are within the context of the definition of entrepreneur (see page 4), but are also some of the hallmarks of intrapreneurism (Pinchot 1985; Antoncic and Hisrich 2003).

The principle difference between entrepreneurs and intrapreneurs is the acceptance of personal risk. Intrapreneurs are calculated risk-takers who are able to transfer personal risk to organizational risk. They still innovate, but share the risk (Pinchot 1985; Antoncic 2003).

This research is exploratory, cross-disciplinary, and integrative. It offers insight by using mixed methods from differing samples to explore an exceptionally high rate of entrepreneurial orientation among graduating engineers. This is coupled with an observable $41 \%$ increase in entrepreneurial outlets between the three graduating cohorts. As cited by the respondents of the engineering graduates, familiarity with technology, computers and abstract thinking was vital. The period of time between 1954 and 1964 showed a marked increase in awareness of digital technology and information systems. Engineers have different forms and types of knowledge. Engineers think differently. Engineers innovate and solve problems.

Research shows the coming years will have higher turnover, especially among knowledge workers. We posit that engineers, as not only knowledge workers, but likely high potential knowledge workers, will continue to gravitate towards entrepreneurial outlets at an increasing rate. The moderator to this may be an organization's ability to calculate the value of knowledge in a manner that allows for equitable compensation for potential knowledge.

\section{References}

Allen, T. J., \& Katz, R. (1995). The project-oriented engineer: a dilemna for human resource management. R\&D Management, 25, 129-140.

Amit, R., \& Zott, C. (2001). Value creation in e-business. Strategic Management Journal, 22(6-7), 493-520.

Antoncic, B. (2003). Risk taking in intrapreneurship: translating the individual level risk aversion into the organizational risk taking. Journal of Enterprising Culture, 11(1), 1-23.

Antoncic, B., \& Hisrich, R. D. (2003). Clarifying the intrapreneurship concept. Journal of Small Business and Enterprise Development, 10(1), 7-24.

Baker, H. G., \& Echarananta, N. (1999). Capturing entrepreneurial values. Journal of Applied Social Psychology, 29(4), 820-833.

Baldwin, C. Y. (2010). "The strategic use of architectural knowledge by entrepreneurial firms". Presented at the "opening up innovation: strategy, organization and technology" conference, imperial college London business school, June 16-18. Accessed July 12, from http://scholar.google.com/scholar_url?hl=en\&q= http:/www2.druid.dk/conferences/viewpaper.php\%3Fid\%3D501471\%26cf\%3D43\&sa=X\&scisig= AAGBfm2NMAEWsdOoCyHjqswO063L2-eynQ\&oi=scholarr. 
Baron, J. M., Hannan, T., \& Burton, M. D. (2001). Labor pains: change in organizational models and employee turnover in young, high-tech firms. American Journal of Sociology, 106(4), 960-1012.

Bharadwaj, S. G., Varadarajan, P. R., \& Fahy, J. (1993). Sustainable competitive advantage in service industries: a conceptual model and research propositions. Journal of Marketing, 57, 83-99.

Birch, D. (1979). The job generation process. Cambridge: M.I.T. Program on Neighborhood and Regional Change.

Bowman, C., \& Ambrosini, V. (2000). "Value creation versus value capture: towards a coherent definition of value in strategy". British Journal of Management, 11(1), 1-15.

Cariand, J. W., Hoy, F., Boulton, W. R., \& Carland, J. A. (1984). Differentiating entrepreneurs from small business owners: a conceptualization. Academy of Management Review, 9, 354-359.

Chandler, A. D., Jr. (1990). Scale and scope. Cambridge: The Belknap Press of Harvard University Press.

Cohen, W., \& Levinthal, D. (1990). Absorptive capacity: a new perspective on learning and innovation. Administrative Science Quarterly, 35(25), 128.

Coleya, F., Housemana, O., \& Roya, R. (2007). An introduction to capturing and understanding the cognitive behaviour of design engineers. Journal of Engineering Design, 18(4), 311-325.

Covin, J. G., \& Slevin, D. P. (1989). Strategic management of small firms in hostile and benign environments. Strategic Management Journal, 10(1), 75-87.

Cox, M. F. (2011). "Engineering is everywhere," Keynote address, accessed April 17th, 2012 at http:// freedownload.is/ppt/fortune-500-ceo.

Das, T. K., \& Teng, B.-S. (1998). Time and entrepreneurial risk behavior. Entrepreneurship: Theory and Practice, 22(2), 69-88.

Farlie, R. W. (2013). "Kauffman index of entrepreneurial activity" April 7, 2013. Accessed at http://www. kauffman.org/what-we-do/research/kauffman-index-of-entrepreneurial-activity.

Felicelli, M., \& Allen, K. (2006). "2006 Route to the top”, Spencer Stewart, accessed at: http://content. spencerstuart.com/sswebsite/pdf/lib/2005_CEO_Study_JS.pdf.

Felin, T., \& Hesterly, W. S. (2007). The knowledge-based view, nested heterogeneity, and new value creation: philosophical considerations on the locus of knowledge. Academy of Management Review, 32(1), 195218.

Gross, A. C. (1968). "Engineering manpower in Canada". Unpublished Ph.D. thesis. Columbus: Ohio State University.

Gross, A. C. (1969a). On engineering education and engineering students. Journal of Higher Education, 40(7), 520-533.

Gross, A. C. (1969b). Patterns and determinants of income of Canadian engineering graduates. Industrial and Labor Relations Review, 23(1), 52-64.

Gurka, S. (2011). "Why engineers could make the best business leaders." Business Insider, December 18, 25.

Heunks, F. J. (1998). Innovation, creativity and success. Small Business Economics, 10(3), 263-272.

Hoffman, N. P. (2000). An examination of the 'sustainable competitive advantage' concept: past, present, and future. Academy of Marketing Science Review, 20, 1-16.

Hunt, S. D., \& Morgan, R. M. (1995). The comparative advantage theory of competition. Journal of Marketing, 59, 1-14.

Keller, B. (2013). "The bloomberg legacy," New York Times, July 15, A17.

Kennedy, C. (2001). "Show me the money," Director, Nov. 2001, 55(4), p103

Kotelnikov, V. (2001). "Collecting, leveraging, and distributing both explicit and tacit knowledge throughout your organization", retrieved March 25, 2002 from www.1000ventures.com/.

Lavoie, M., \& Finnie, R. (1998). The occupational dynamics of recent Canadian engineering graduates inside and outside the bounds of technology. Research Policy, 27(2), 143-158.

Lee, T. W., \& Maurer, S. D. (1997). The retention of knowledge workers with the unfolding model of voluntary turnover. Human Resources, Management Review., 3, 247-275.

Lepak, D. P., Smith, K. G., \& Taylor, M. S. (2007). Value creation and value capture: a multilevel perspective. Academy of Management Review, 32(1), 180-194.

Li, T., \& Calantone, R. J. (1998). The impact of market knowledge competence on new product advantage: conceptualization and empirical examination. Journal of Marketing, 62(4), 13-29.

Lowendahl, G., Revang, O., \& Fosstenlokken, S. (2007). Knowledge and value creation in professional service firms: a framework for analysis. Human Relations, 54(7), 911-931.

Lumpkin, G. T., Brighamb, K. H., \& Moss, T. W. (2010). "Long-term orientation: implications for the entrepreneurial orientation and performance of family businesses". Entrepreneurship and Regional Development: An, International Journal, 22(3-4), 241-264.

Mark, J., \& Johnson, G. (2003). "Entrepreneurial intentions and outcomes: a comparative causal mapping study”. Journal of Management Studies, 34(6), 895-920. 
Martelli, J., \& Abels, P. (2010). The education of a leader: educational credentials and other characteristics of chief executive officers. Journal of Education for Business, 85, 209-217.

Matusik, S., \& Hill, C. (1998). The utilization of contngent work, knowledge creation, and competitive advantage. Academy of Management Review, 23(4), 680-697.

Moti, F. (2006). Knowledge, abilities, cognitive characteristics and behavioral competences of engineers with high capacity for engineering systems thinking (CEST). Systems Engineering, 9(2), 91-103.

Pinchot, G. (1985). Intrapreneuring. New York: Harper and Row.

Polanyi, M. (1958). Personal knowledge: Towards a post-critical philosophy. Chicago: University of Chicago Press.

Ryoo, J., \& Rosen, S. (2004). The engineering labor market. Journal of Political Economy, 112(1), S110S140.

Sachoff, M. (2008). “A 3\% decrease since 1983”, Smallbusinessnewz.com, accessed at http://www. smallbusinessnewz.com/number-of-americans-starting-small-businesses-declining-2008-01.

Shane, S. (2012). "Start up failure rates: the definitive numbers, small business trends, Dec.12. Accessed at: http://smallbiztrends.com/2012/12/start-up-failure-rates-the-definitive-numbers.html.

Smith, K. B. (2002). Typologies, taxonomies, and the benefits of policy classification. Policy Studies Journal., 30(3), 379-395.

Solymossy, E. (2000). Entrepreneurial dimensions: the relationship of individual, venture, and environmental factors to success. Entrepreneurship: Theory and Practice, 24(4), 79-90.

Solymossy, E. (2011). "The value of knowledge; applied versus potential." Working Paper. Western Illinois University - Quad Cities.

Solymossy, E., Chowhan, J., \& Gross, A. (2012). Taking the engineering path to business leadership and entrepreneurial success in Canada and USA. International Journal of Educational Advancement, 11, 1.

Srivastava, R. K., Shervani, T. A., \& Fahey, L. (1998). Market-based assets and shareholder value: a framework for analysis. Journal of Marketing, 62, 2-18.

Stevens, M. J., \& Campion, M. A. (1994). The knowledge, skill, and ability requirements for teamwork: implications for human resource management. Journal of Management, 20(2), 503-530.

Tremblay, M., Wils, T., \& Proulx, C. (1998). "Determinants of desired career paths among Canadian engineers". Scientific series paper, 98s-15. Montreal: CIRANO at HEC/UM.

Tremblay, M., Gianecchini, \& Wils, T. (2007). "Determinants of subjective and objective success among Canadian and french engineers". 18ieme Congres de AF/AGHR, 1-23.

Unknown. (2011). "Employee turnover expected to rise in next five years", accessed on Jan 13, 2014, at http:// www.right.com/news-and-events/pressreleases/2011-press-releases/item21771.aspx.

Unknown. (2013a). "Origins of engineering”, accessed on July 8, 2013, at http:/www.seas.ucla.edu/hsseas/ history/origin.html.

Unknown. (2013b). "The beginnings of engineering in Canada", in The EIC Virtual Museum Project, accessed on July 8, 2013 at http://power.eng.mcmaster.ca/findlay/eicweb/virtual.html.

Vesey, J. T. (1991). The New competitors: they think in terms of 'speed-to-market. Academy of Management Perspective, 5(2), 23-33.

Von Glinow, M. A. (1988). The new professionals. Cambridge: Ballinger.

White, W. E. (2002). Engineering education in Canada. World Transactions on Engineering and Technology Education, 1(2), 163-167.

Whittaker, J. (2001). Engineers, entrepreneurs, and the commercialization of technology. Proceedings of the Portland International Conference on Management of Engineering and Technology, 2, 81-84.

Wilson, A. H. (1998). The Engineering Journal as a source for the history of engineering in Canada. History \& Archives Working Paper. Ottawa: Engineering Institute of Canada.

WSJ (2013). "53 percent of Americans consider starting their own start-up". Wall Street Journal, July 15. Accessed at http://online.wsj.com/article/PR-CO-20130715-907828.html?mod=wsj_share_twitter. 